\title{
КАКИЕ МЕЖДУНАРОДНЫЕ СУДЫ НУЖНЫ ДЛЯ СНГ?
}

\author{
М.И. К л е а н д р о в*
}

В целом сегодня в российском обществе (и, видимо, в общественном сознании других государств-участников СНГ) превалирует достаточно пессимистический взгляд на будушее СНГ. Для этого есть серьезные основания; тем не менее есть и объективные предпосылки для осторожного оптимизма относительно будуших интеграционных, пусть разноскоростных, разновекторных и пр. процессов в СНГ.

За время своего существования СНГ - с точки зрения организационно-правового обеспечения - прошло немалый путь, который схематично можно представить в виде нескольких этапов, каждый из которых характеризуется важным действием: 1) объявлением о создании СНГ с одновременным прекращением СССР; 2) юридическим оформлением опорно-правового “каркаса" СНГ - Устава Содружества; 3) заключением договора об Экономическом союзе; 4) созданием первого органа СНГ с определенными надгосударственными полномочиями - Межгосударственного экономического комитета - МЭКа; 5) решением о создании Таможенного союза и т.д. С большой долей условности можно сказать, что каждый из перечисленных исторических этапов есть определенная веха, свидетельствуюшая о намерении обеспечить качественно более высокяй, по сравнению с предыдущим, уровень интеграционных процессов и уровень интеграции в СНГ - интеграции межтосударственной, межведомственной, межхозяйственной и межличностной одновременно.

Сегодняшнее же состояние СНГ - с точки зрения уровня и степени его интеграции, точнее - организационно-правового обеспечения интеграционных процессов можно охарактеризовать следующими показателями: а) создан, юридически оформлен и реально действует правовой фундамент СНГ, "скрепляющий" суверенные государства в Содружество; б) созданы и действуют, хотя подчас и недостаточно эффективно, органы и институты Содружества, призванные обеспечивать в СНГ координацию в экономической, оборонной, научной, образовательной, культурной и иных областях на межгосударственном и более низких уровнях; в) заключены, хотя процентов на 80 не исполняются, многочисленные многосторонние межгосударственные и межправительственные соглашения в рамках СНГ, к тому же нет механизма ответственности за их неисполнение; r) набирает “обороты" процесс заключения двух-, трех-, четырехсторонних межгосударственных и межправительственных соглашений и договоров между государствами СНГ, направленных на установление качественно более тесных интеграционных отношений (по сравнению с отношениями между другими государствами Содружества) на разных уровнях и в разных сферах (типичный пример - Союзное государство Беларусь-Россия). Таким образом, в

* Член-корреспондент Российской Академии Наук, подробнее об авторе см. № 1 нашего журнала за 1998 год. 
рамках Содружества процессы интеграции становятся разновариантными, разносубъектными, разновекторными и разноскоростными, более того - они становятся доминирующими; д) в развитии интеграции наметился переход от бессистемного "шараханья" с элементами авантюризма к стратегическому планированию на основе утвержденного Перспективного плана интеграционного развития СНГ; е) создаются и Межпарламентской Ассамблеей СНГ принимаются рекомендательные (модельные) законодательные акты, в том числе - кодексы для всех государств Содружества; ж) созданы и действуют специальные юридические органы СНГ - Экономический Суд, Правовой консультативный совет и Научно-консультативный центр частного права СНГ.

Интеграционные процессы, идущие в СНГ на многих уровнях, не всегда динамичны, прямолинейны и равнопоступательны. Тем не менее уже сегодня уровень и степень интеграции, как и инфрастуктура, обеспечивающая интеграционные процессы в СНГ, внушительны. В то же время сегодня СНГ - не только не государство, в том числе конфедеративное (высказанная в литературе точка зрения, согласно которой конфедерация является "лишь достаточно слабым и неустойчивым союзом независимых государств, не имеющим международной правосубъектности, единых органов власти и управления, единой правовой системы и т.д. У нее могут быть один или несколько органов, права и компетенция которых ограничены целями, обусловившими создание конфедерации: оборона, установление общих таможенньх тарифов и пошлин и др. Юридическая расторможенность по воле ее членов - главный правовой признак конфедерации"1) применительно к сегодняшнему СНГ означает, что оно конфедерация, что вряд ли правильно), но пока и не союз государств, степень межгосударственного объединения в котором на пюрядок выше (по общепринятым критериям), чем в межгосударственных образованиях типа сообщество (Европейский союз на первоначальном этапе своего интеграционного развития именовался Европейским Экономическим сообществом) или содружество. Но условия для перехода на качественно более высокий уровень межгосударственной интеграции в СНГ налицо, и главное здесь условие - не политика, не экономика и даже не "общий враг за бугром" (который сейчас отчетливо - на южных рубежах СНГ - просматривается), а единая в совсем недавнем прошлом общность советских людей, сравнительно общая мораль, нравственность, менталитет, история и т.д., что не может не сказываться сегодня на “общеэсэнгэшном" пространстве и будет сказываться впредь, а отсюда - обязанность политиков эту данность воспринимать и ею руководствоваться.

Вообще любой союз государств - Экономический, Таможенный, Торговый и др. в СНГ здесь не исключение - это достаточно высокая стадия интеграционного объединения государств. Другое дело, что степень интеграции и в межгосударственном союзе может быть различной и в своем развитии пройти несколько этапов. Но тем не менее следующая, после союза государств, стадия межгосударственной интеграции, это уже государственное образование, вначале конфедеративное, потом федеративное, а затем и унитарное, и СНГ вовсе необязательно все эти стадии проходить. Сегодня же, по крайней мере, реальная аморфность 
интеграции государств в Содружестве еще столь велика, что о подлинном вхождении государств во вторую фазу межгосударственной интеграции - союз государств (пусть - Экономический союз) говорить преждевременно. В значительной мере успех в продвижении по пути усиления интеграционных процессов в СНГ на всех уровнях будут зависеть от того, каким образом, какими способами, в каких формах, по каким процедурам будут решаться различные спорные вопросы возникаюшие в межгосударственной сфере, между другими субъектами разных государств Содружества и т.д. - на пространстве СНГ.

Пожалуй, на сегодня можно назвать лишь две категории споров, для разрешения которых предусмотрены соответствующие механизмы, приводимые “в движение” существующими судебными органами. Это: а) экономические споры между хозяйствующими субъектами разных государств Содружества, которые, в соответствие с межправительственным Соглашением о порядке разрешения споров, связанных с осуществлением хозяйственной деятельности (Киев, 20 марта 1992 г.) разрешают национальные арбитражные, хозяйственные, экономические суды и другие судебные органы государств Содружества; б) межгосударственные экономические споры, возникающие при исполнении экономических обязательств, предусмотренных соглашениями, решениями Совета глав государств, Совета глав правительств Содружества и других его институтов, и о соответствии нормативных и других актов государств-участников Содружества, принятых по экономическим вопросам, соглашениям и иным актам Содружества, которые разрешает Экономический Суд СНГ. Кроме того, рядом отдельных многосторонних межгосударственньх и рядом двухсторонних (например, межправительственное Соглашение между Россией и Кыргызтаном от 9 апреля 1993 r. о сохранении специализации промышленных предприятий) межгосударственных соглашений государств Содружества предусмотрено, что споры по ним (частично или целиком - неэкономического характера) также будут решаться Экономическим Судом СНГ. Все же остальные категории и виды споров в СНГ, межгосударственные или находящиеся на межгосударственных “стыках", не имеют межгосударственного механизма своего разрешения. Правовая природа этих споров в СНГ различна; они "вытекают" и из международно-правовых, и из гражданско-правовых и из иных правовых отношений; различаются они и по предмету, и по субъектному составу, и по другим критериям. В основном для пространства СНГ это качественно новые споры.

Классическим примером здесь могут служить труповые споры_ органах. институтах СНГ. Речь идет о трудовых спорах между работодателем - органом, институтом Содружества, с одной стороны, и работником этого органа - межгосударственным служащим, который де-юре должен быть защищен от национальной юрисдикции государства местонахождения своего работодателя, как минимум - в части выполнения им своих служебных обязанностей. Правовое положение "штатных" работников органов и институтов Содружества определяется (далеко не в достаточной степени) прежде всего в положениях и уставах (и иных актах) об этих органах и институтах. Более подробная регламентация по данному вопросу содержится в Общем положении о межгосударствен- 
ных (межправительственных) органах СНГ, утвержденном решением Совета глав правительств Содружества 21 октября 1994 г. Важным представляется юридическое закрепление в Общем положении правила, согласно которому служащие межгосударственного (межправительственного) органа СНГ не подлежат юрисдикция государства пребывания в отношении действий, совершаемых ими при исполнении служебных обязанностей.

Штатная численность некоторых органов и институтов Содружества составляет десятки людей, обшая штатная численность всех органов и институтов СНГ - сотни сотрудников в ранге международных служащих. Для сравнения - в органах Европейского Союза работает сегодня около 20 тыс. человек. Так что вопрос о том, кто и как будет разрешать трудовые споры с участием тех сотрудников органов и институтов СНГ, которые обладают иммунитетом от национальной юрисдикции, отнюдь не надуманный. В структурах Европейского Союза такие споры разрешает Суд Европейского Союза, точнее - его Суд первой инстанции; иногда судебное дело по трудовому спору там тянется по 3 года, а предмет требований с наших позиций бывает удивительным, например, о возмещении ущерба, вызванного непереводом несколько лет назад (до подачи судебного иска) служащего одного из органов ЕС, ныне пенсионера, на вакантную в то время должность более высокой и лучше оплачиваемой должностной "ступеньки".

Конечно, органы и институты Содружества комплектуются специалистами высокой квалификации, к сутяжеству обычно не предрасположенными. Да и трудовой спор - в первых его стадиях - может и должен быть рассмотрен традиционным путем - небезысвестной комиссией по трудовым спорам, а затем, при необходимости - профкомом, созданным в органе, институте Содружества как работодателе. Но при недостижении в них согласия (тем паче, если они вообще не созданы) межгосударственный стужащий СНГ должен иметь возможность межгосударственной судебной защиты свокх трудовьх и связанных с ними прав и законных интересов.

Можно также назвать латентные межгосударственные территориальные спорь в СНГ. На уровнях глав государств и глав правительств, министров иностранньх дел и др. В Содружестве принято множество соглашений, решений, деклараций, меморандумов и т.д. о незыблемости государственных границ и неприкосновенности территорий государств СНГ, отказе от территориальных притязаний и т.п. Но беда в том, что в межгосударственном территориальном споре почти всегда, за, быть может, редчайшими искпочениями, оба споряших государства, претендуя на одну и ту же территорию, считают ее своей; каждое государство в этом случае не считает себя нарушителем договоров и соглашений о неприкосновенности чужих территорий и каждое, даже направляя вооруженные силы в этот очаг международного конфликта, действует сообразуясь с патриотическим лозунгом: “чужой земли нам не надо, но своей не отдадим ни пяди".

Исключительные особенности государственных границ в СНГ заключаются в том, что они - фактически не межгосударственные границы, что по сути дела государственных границ между союзными республиками в СССР не было. Известно, что границы большинства 
союзных республик в 20-е годы "кроились" произвольно и в деталях документально не закреплялись, особенно в ходе так называемого “национального размежевания" в Средней Азии. Ныне много территорий по несколько десятков и даже сотен квадратных километров на границах суверенных государств СНГ с точки зрения их государственной принадлежности не определены и это общеизвестно. Соответствующей демаркацией границ в СНГ не занимаются. Считать, что и дальше конфликтов, могущих перерасти в межгосударственные споры, не будет, вряд ли следует; точнее - надеяться на это можно, но готовиться $\mathrm{k}$ худшему повороту событий нужно. Альтернатива судебному спору переход разрешения территориального конфликта мирными средствами в межгосударственный территориальный спор, разрешаемый вооруженными силами. В юридической литературе прямо указывается, что конфликты на территории СНГ порождены в основном обострением вопросов национально-территориального размежевания после распада $\mathrm{CCCP}^{2)}$. Как отмечается в периодической печати, эксперты Федеральной пограничной службы РФ прогнозируют сейчас вероятность территориальных проблем у России с Украиной и Грузией, Азербайджаном и Казахстаном ${ }^{3)}$. Немало общеизвестных территориальных противостояний - пока, слава богу, мирных - между Казахстаном и Узбекистаном, между Тапжикистаном и Кыргызтаном (в последнем случае территориальные притязания усугубляются дефищитом водных ресурсов и общими (в прошлом) ирригационными сооружениями) и т.д. Конечно, есть в Содружестве Объединенные Вооруженные силы, нет и явно в будушем не будет недостатка в политиках, желающих стать миротворцами, в том числе - из дальнего зарубежья, поэтому имеется надежда, что в случае обострения межгосударственного территориального спора удастся "приглушить", "потушить" или даже предотвратить военный способ его разрешения, но, во-первых, надежда эта - не стопроцентная вероятность, чему история, к сожалению, знает немало подтверждений, а во-вторых, и при положительном итоге процесс разрешения данного межгосударственного территориального спора должен протекать в правовом русле. И здесь наиболее оптимальное решение - судебный способ разрешения спора в международных судебно-процессуальных формах.

Каждое из государств Содружества ныне считает себя правовым и для каждого из них не все равно - выполнять решение о прекращении территориального конфликта, вынесенное, например, группой посредников, представителями ОБСЕ и т.П., являющееся сугубо политическим решением, или не выполнять судебное решение, сутубо правовое, вынесенное международным судом в полном соответствии с его компетенцией, которой данный суд наделен в том числе и государствами-участниками конкретного территориального спора. Внутригосударственные территориальные споры - это дело самого государства, так сказать - его проблемы, если, конечно, там не нарушаются права человека.

Споры (лела) о соответствии законов госуларств Солружества межгосуларственным соглашениям и иным актам Солружества. Во множестве межгосударственных соглашений, договоров, деклараций и пр., принятых на уровне глав государств (и уровнем ниже) СНГ провозгла- 
шена приоритетность международных актов над национальным законодательством. Это общий принцип права, он закреплен и конституционно: например, часть 4 ст. 15 Конституции Российской Федерации гласит: "Если международным договором Российской Федерации установлены иные правила, чем предусмотренные законом, то применяются правила международного договора". И такой подход ни в коей мере не ограничивает суверенитет государства. Но как быть в реалии, если выясняется: тот или иной закон (его отдельная норма) или даже положение Конституции конкретного государства Содружества находится в противоречии (в несоответствии) с межгосударственным актом (договором, соглашением и пр.) СНГ? Последовательность принятия (заключения) несоответствующих друг другу национальных законов и межгосударственньх соглашений может быть самая различная - закон мог быть принят (или изменения в ранее принятый закон могли быть внесены) позже заключения межгосударственного соглашения (равно - его ратификации) или наоборот - не суть важно. Главное - несоответствие есть, обнаружилось, и надо решить, как данною коллизию разрешить?

Это - не схоластическое теоретизирование: ни создание общего правового пространства СНГ, ни построение государств Содружества в качестве правовых невозможно без полного соответствия внутреннего национального законодательства государств Содружества международноправовым актам и прежде всего - актам самого Содружества. А это требует, в свою очередь, механизма “отслеживания" противоречивости национального законодательства (всей законодательно-нормативной базы) каждого государства Содружества актам СНГ. И, безусловно, необходим судебный механизм рассмотрения дел о таком несоответствии в случае его обнаружения. Безусловно, обе функции должны выполнять межгосударственные органы СНГ. В роли механизма “отслеживания" мог бы выступать Правовой консультативный совет СНГ. Видимо, вопрос о несоответствии национального законодательного акта межгосударственному акту СНГ предварительно должен быть рассмотрен национальным конституционным судом страны, принявший этот законодательный акт.

Межобластные споры. Достаточно широко распространилась практика заключения двух- и более сторонних договоров между приграничными областями разных государств Содружества. Например, в январе 1995 г. между Витебской и Новгородской областями было заключено двухстороннее соглашение о долгосрочном торгово-экономическом, научно-техническом и культурном сотрудничестве, предусматривающем, в частности, содействие в установлении прямых хозяйственных связей, оказание услуг в коммерческой и маркетинговой сферах, разработку программы по углублению научно-технических и культурных связей, организацию взаимопомощи по ликвидации последствий стихийных бедствий и катастроф и т.П. Это не тот случай, когда договор подписывают руководители двух государств (или их уполномоченные представители) в интересах своих приграничных областей - названное соглашение подписали руководители администраций обеих областей. Это и не декларативный “протокол о намерениях", и не политический договор о дружбе и взаимопонимании. Это полнокровный договор с 
серьезной доминантой в нем конкретных организационно-экономических обязательств каждой из сторон. В январе 1995 г. протоколом о взаимовыгодном двустороннем сотрудничестве между Харьковской и Московской областями (подписанными председателем Харьковского облсовета и главой администрации Московской области) предусмотрено создание ряда совместных предприятий, реализация Московских инвестиционных программ в Харьковском регионе и пр. Встает вопрос о механизме разрешения споров, возникающих при неисполнении и/или неналлежашем исполнении договоров между областями разных государств СНГ.В рассматриваемой плоскости лежит и проблема механизма разрешения споров по соглашениям между субъектом Российской Федерации и государством Содружества (в 1994 г., например, Тюменская область заключила договоры об экономическом сотрудничестве с Узбекистаном, Казахстаном, Таджикистаном и т.д.), между субъектом Федерации и автономной республикой государства Содружества и т.д. Вряд ли здесь речь идет о спорах между участниками публичных - международных отношений; но в принципе можно говорить об участниках частных - гражданско-правовых отношений - для России в реалии на базе ст. 124 ГК РФ, а для государств Содружества - в потенции, когда и если в их ГК будет воспринята редакция ст.148 модельного для государств Содружества ГК. Федеральный закон "О координации международньх и внешнеэкономических связей субъектов Российской Федерации" от 2 декабря 1998 г. носит внутригосударственный характер, он регулирует отношения между Российской Федерацией и ее субъектами и вопрос о механизме разрешения внешнеэкономических споров с участием субъекта Федерации оставляет, естественно, вне своего правового воздействия.

Межотраслевые (межведомственные) споры в СНГ. Речь идет о спорах по условиям соглашений, заключенных министерствами, ведомствами, иными отраслевыми органами государственного управления стран СНГ. Такие двух- и более сторонние межотраслевые соглашения широко практикуются в Содружестве, более того - в ряде случаев их заключение прямо предусматривается межправительственными соглашениями. Например, статьей 2 Соглашения от 9 сентября 1994 г., заключенного главами правительств всех 12-ти государств Содружества, определяющего вопросы поставок товаров для обеспечения национальных гидрометеорологических служб государств-участников СНГ, предусмотрено, что объемы товаров, подлежащих вывозу (ввозу), определяются двусторонними договорами (контрактами) между национальными гидрометеорологическими службами государств-участников СНГ. Статьей 1 Соглашения от 9 декабря 1994 г. о товарообороте и производственной кооперации в области машиностроения на взаимоувязанной основе главы правительств 11-ти государств Содружества (за исключением Туркменистана) прямо поручили машиностроительным министерствам и ведомствам с согласия предприятий заключать ежегодно соглашения о товарообороте продукции машиностроения, включая сырье, материалы для ее изготовления и производственную кооперацию. Статьей 1 межправительственного Протокола о механизме реализации Соглашения об общих условиях и механизме поддержки развития производст- 
венной кооперации предприятий и отраслей государств-участников СНГ от 15 апреля 1994 г. признано "целесообразным содействовать развитию взаимовыгодной специализации производства на основе долгосрочных отраслевых и межотраслевых соглашений”, при этом в качестве Приложения №1 $\mathbf{k}$ данному Протоколу правительствами согласовано Примерное соглашение о производственной кооперации между министерством (ведомством) одного государства СНГ и министерством (ведомством) другого государства СНГ. Характерно, что в ст.7 этого Примерного двустороннего "межотраслевого" соглашения определено следующее: "все спорные вопросы, которые могут возникнуть между предприятиями при поставках продукции в соответствии с настоящим Соглашением, будут разрешаться на условиях, предусмотренных во внешнеторговых контрактах (договорах)", что само по себе весьма спорно. Но главное - ни слова не сказано о том, в каком порядке и кем будут решаться спорные вопросы между самими министерствами (ведомствами) - участниками данного Соглашения.

Далее. Совет глав правительств государств Содружества принял 9 декабря 1994 г. решение о развитии выставочно-ярмарочной деятельности в СНГ. Хорошо известно, что споры об условиях логоворов купли-пролажи. поставки и лругие, могушие возникнуть в прошессе их заключения на выставках и ярмарках, должны быть разрешены в самые короткие - по сравнению с другими категориями споров - сроки, до завершения работы самих выставок и ярмарок. Когда выставка, ярмарка замыкается "рынком" одного государства, для целей разрешения "преддоговорных" споров создается арбитраж ярмаркома, либо эта функщия возлагается на сам ярмарком. При проведении международных ярмарок такой способ также нередко применяется, но процедура укомплектования арбитража ярмаркома представителями государств, фирм или отраслей, которые участвуют в ярмарке, сложна; сам процесс разрешения там преддоговорных споров на всех этапах, включая рассмотрение жалобы на решение, обычно где-либо не "прописан" и создается на месте, нося тем самым разовый характер, к тому же орган, разрешающий эти - безусловно, правовые - споры судебным ни в какой части не является. Да и в процессе исполнения договора нередко сторонам необходимо судебное толкование его положений. Оптимальным выходом из положения было бы “подключение" к разрешению преддоговорных споров на международных выставках и ярмарках международного судебного органа СНГ в форме, например, проведения выездных заседаний одной из коллегий Суда.

Общим положением о межгосударственных (межправительственных) органах СНГ, утвержденным решением Совета глав правительств Содружества от 21 октября 1994 г. предусмотрено, что эти органы могут наделяться правами юридического лица, обладать обособленным имуществом, приобретать права и принимать на себя обязательства по договорам, быть истцом и ответчиком в судах, наделять создаваемые ими органы правами юридического лица, если это установлено соответствующими уставами и положениями об этих органах. Они обеспечиваются служебными помещениями и необходимым имуществом в порядке и на условиях, определяемых по соглашению с государством пребыва- 
ния. А те из них, которые наделены правами юридического лица, могут для решения возложенных на них задач образовывать и иметь в своем распоряжении фонды и резервы, распоряжаться валютой и другими финансовыми активами как внутри, так и вне государства пребывания. Таким образом, органы и институты Содружества выступают в качестве широкого круга участников гражданских правоотношений, стороной в гражданско-правовьх и предпринимательских договорах. Это договоры аренды, найма, подряда, купли-продажи и множества иных с предприятиями, организациями, учреждениями, предпринимателями, гражданами и другими субъектами как государства своего местопребывания, так и друтих государств Содружества. Но ведь это межгосударственные органы с определенным иммунитетом от национальной юрисдикции государства их местопребывания. Могут ли национальные судебные органы государств решать гражданско-правовые споры с кх участием? Вряд ли.

Гражданско-правовые (имущественного, прежде всего, порядка) споры могут возникнуть и у органов, и у институтов Содружества между собой (по договору совместно арендуемого, например, помещения, оборудовании и пр.); споры здесь могут возникнуть с самим государством Содружества (любым, не только своего местопребывания), либо с его административно-территориальной единицей.

Наконец, органы и институты Содружества правомочны принимать (издавать) акты, а в ряде случаев - и акты квазираспорядительного характера (МЭК, например). По идее акты органов и институтов Содружества должны быть приняты в пределах их компетенции и соответствовать актам самого Содружества, прежде всего - создающим его "опорно-каркасную решетку”, в частности - Уставу СНГ и договорам о создании Экономического, Таможенного и др. союзов. Данные “опорные” акты есть своеобразная конституция СНГ, это акты высшей иерархической силы для других актов Содружества, тем более для актов органов и институтов Содружества. Следовательно, в СНГ должен действовать международный судебный орган, во-первых, правомочный разрешать цражланско-правовые спорыс участием органов, институтов Солружества, а во-вторьх, выполняющий роль межгосударственного "конституционного" суда - правомочным проверять соответствие актов органов и институтов Сопружества и, быть может, ряда актов самопе Содружества, основополагаюшим актам СНГ, а при несоответствии - выносить судебное решение об их отмене.

Споры и лела. вытекаюшие из созлания н леятельности транснашиональных объелинений СНГ. Здесь нужно учесть, что: а) формально ряд видов споров этой категории может быть рассмотрен национальными арбитражными, хозяйственными судами государств Содружества на основании Киевского (от 20 марта 1992 г.) Соглашения о порядке разрешения споров, связанных с осуществлением хозяйственной деятельности; б) в учредительных документах транснационального объединения СНГ может быть заложен иной порядок разрешения споров; в) как сами транснациональные объединения СНГ, так и хозяйствующие субъекты, в них входящие, а также их филиалы и отделения без прав юридического лица должны обладать некоторым иммунитетом от национальной арбитражно(хозяйственно)-судебной системы государства их 
местонахождения, что послужит дополнительным стимулом инвестирования из иностранных источников в объединение.

Ведь речь идет о спорах и делах: между учредителями разных государств Содружества (где в числе учредителей есть государственные органы) одного транснационального объединения; между хозяйствующими субъектами разных государств Содружества, входящими в состав одного транснационального объединения; между хозяйствующим субъектом, входящим в состав транснационального объединения, с одной стороны, и органом управления этого объединения, с друтой; между филиалами, отделениями одного транснационального объединения; о соответствии учредительных документов транснационального объединения СНГ актам Содружества либо актам органов, институтов Содружества; о толковании норм учредительных документов транснационального объединения СНГ; о признании экономической несостоятельности (банкротстве) транснационального объединения СНГ, проведения санации, назначения внешнего (арбитражного) управляющего и т.д.; о признании деятельности транснационального объединения противоречащей актам Содружества, например, в части антимонопольных ограничений. Все эти дела и споры должен, безусловно, решать международный судебный орган Содружества.

Наконец, есть категории споров, которые не могут быть по тем или иным причинам “включены” в обязательную юрисдикцию межгосударственного судебного органа СНГ, но разрешение их в нем целесообразно. Вопрос может быть решен путем предоставления этому судебному органу правовьх возможностей разрешать нижеперечисленные виды споров в режиме третейского судопроизводства. Это: а) межгосударственные споры, вытекающие из двух- и многосторонних межтосударственных соглашений (по поводу нарушения соглашений либо их толкования), когда, например, одной стороной в споре является государство-участник Соглашения о статусе Экономического Суда СНГ от 6.07.92 г., а другой: либо государство-участник Содружества, но не участник Соглашения от 6.07 .92 г.; либо государство-неучастник Содружества; б) споры, прежде всего имущественные, вытекающие как из двусторонних договоров и соглашений, так и из деликта, где одной стороной является орган, институт Содружества, а другой: либо государство, не участник Содружества; либо министерство, ведомство государства-неучастника Содружества; либо хозяйствующий субъект государства-неучастника Содружества; либо гражданин государства-неучастника Содружества.

Все перечисленные категории и группы дел можно, с определенной долей условности, отнести к экономическим. Поэтому, в принципе, вопрос о механизме их разрешения может быть решен путем радикального реформирования и расширения компетенции Экономического Суда СНГ, тем более, что Совет глав государств Содружества еще 28 апреля 1998 г. издал поручение о разработке проекта новой редакции Положения об этом суде. Но пока юрисдикция Экономического Суда СНГ распространяется даже далеко не на всех государств-участников СНГ, что отмечается в литературе ${ }^{4)}$. Поэтому - в качестве альтернативы - вопрос может быть решен и путем создания 
принципиальноновогомеждународногосудебногооргана, для которого подойдет наименование: Суд Содружества или Высший Суд Содружества (термин "высший" необязательно предполагаетналичие "низших" звеньев).

Исходя из совокупного объема содержательной компетенции Высший Суд Содружества должен будет структурироваться (либо - Экономический Суд СНГ должен быть реформирован) и работать в режиме специализированных коллегий. Предположительно должны быть созданы следующие коллегии:

- Коллегия по разрешению межгосударственных экономических споров. На нее могла бы быть возложена функция дачи толкований актов Содружества, актов органов и институтов Содружества и отдельных актов бывшего СССР - на период взаимосогласованного их применения. Практически вся компетенция сегодняшнего Экономического Суда СНГ (за исключением функции по разрешению споров о соответствии нормативных и друтих актов государств-участников СНГ, принятых по экономическим вопросам, соглашениям и иным актам Содружества) может быть “вмонтирована" в сферу полномочий этой коллегии. Кроме того, Коллегия смогла бы разрешать споры, вытекающие из двусторонних соглашений: между государством Содружества, с одной стороны, и областью (иной территориальной единицей) иного государства Содружества, с другой; между областями (иными территориальными единицами) разных государств Содружества; между министерствами (ведомствами) разных государств Содружества. Дела в нее могли бы поступать после рассмотрения их МЭКом Экономического союза или от него непосредственно либо - для "межотраслевых" споров - от "курирующих" органов, институтов Содружества;

- Коллегия по разрешению трудовых споров и иных споров, вытекающих из трудовых отношений. Это споры - между органом, институтом Содружества, с одной стороны, и работником органа; института Содружества, обладающим иммунитетом от национальной юрисдикции, с другой. Дела в Коллегию могли бы поступать после прохождения традиционных для наших трудовых споров инстанций - созданных и действующих в органах, институтах Содружества комиссий по трудовым спорам и профкомов;

- Коллегия по разрешению межгосударственных территориальных споров. Дела в эту коллегию могли бы поступать: от спорящего государства; от органа, института Содружества; от смешанной межгосударственной комиссии, созданной для ведения работ по демаркации государственной границы;

- Коллегия по рассмотрению дел о соответствии законодательных актов (включая конституции) и других нормативных правовых актов государств Содружества актам самого Содружества, а также актам органов, институтов Содружества, носящим обязательный характер. Эта коллегия также сможет рассматривать дела о соответствии актов органов, институтов Содружества Уставу СНГ, иным межгосударственным соглашениям, другим актам Содружества. Коллегия могла бы разрешать споры между государством Содружества и органом, институтом Содру- 
жества, а также между органами, институтами Содружества; давать судебные толкования актам Содружества, актам органов, институтов Содружества. Дела в эту коллегию должны, видимо, поступать после их рассмотрения и дачи по ним квалифицированного заключения из Правового консультативного совета СНГ;

- Коллегия по хозяйственным (предпринимательским) спорам, в которой должны разрешаться все споры, вытекающие из соглашений, деликта и возникающие по иным основаниям, связанные с транснациональными объединениями СНГ: между транснациональным объединением СНГ и государством Содружества; между транснациональным объединением СНГ и областью (иной крупной административно-территориальной единицей) государства Содружества; между транснациональным объединением СНГ и органом, институтом СНГ; между учредителями (в числе которых - государственный орган) транснационального объединения СНГ; между хозяйствующим субъектом и филиалом, отделением одного транснационального объединения; между хозяйствующими субъектами разных государств Содружества, входящими в состав одного транснационального объединения СНГ; между хозяйствующим объектом, входящим в состав транснационального объединения СНГ, и органом управления этого объединения; между хозяйствуюшим объектом, входящим в состав транснационального объединения СНГ, и государством Содружества. Коллегия сможет рассматривать дела о несоответствии учредительных документов транснационального объединения СНГ актам Содружества, либо актам органов, институтов Содружества; о несоответствии деятельности транснационального объединения СНГ межгосударственным соглашениям, например - в области антимонопольных ограничений; об экономической несостоятельности (банкротстве) транснационального объединения СНГ; кроме того, в ведение коллегии могут быть переданы для рассмотрения и иные споры: между государством Содружества и хозяйствующим субъектом другого государства Содружества (не входящего в состав транснационального объединения СНГ); между хозяйствующим субъектом государства Содружества и органом, институтом Содружества, а также между гражданином государства Содружества и органом, институтом Содружества. Коллегия могла бы взять на себя (в форме, например, выездных судебных заседаний) разрешение преддоговорных споров на международных ярмарках, выставках. Коллегия могла бы давать судебные толкования и выносить консультативные заключения по учредительным документам транснациональных объединений СНГ, договорам и соглашениям между субъектами, споры между которыми входят в ее компетенцию. Дела в эту Коллегию могли бы в отдельных случаях поступать после дачи по ним заключений органов, институтов Содружества, прежде всего - МЭКом, после принятия спорящими сторонами мер по досудебному урегулированию споров и т.п.

В Высшем Суде Содружества (равно - в реформированном Экономическом Суде СНГ) целесообразно предусмотреть трехстадийную процедуру рассмотрения споров (прохождения дел): Предметная коллегия (первая инстанция) - Президиум (кассационная инстанция) - Пленум 
(надзорная инстанция), что обеспечит решениям Суда возможный максимум "устойчивости". Вместе с тем отдельные вопросы, например, судебное толкование актов Содружества, вынесение консультационных заключений по запросам Совета глав государств СНГ, могут стать предметом непосредственного рассмотрения Президиумом и даже Пленумом Суда, минуя коллегии.

Президиум Суда может быть сформирован в нескольких вариантах: а) полный состав судей всех коллегий Суда; 6) состав судей только одной, предметной коллегии плюс председатели всех других коллегий плюс председатель Суда; в) председатели всех коллегий Суда плюс председатель Суда; г) состав судей одной, предметной коллегии плюс председатели тех Высших (Верховных) Судов государств Содружества, деятельность которых соответствует профилю коллегии, например, коллегии же по рассмотрению дел о соответствии законодательных актов государств СНГ актам Содружества соответствует деятельность Конституционных судов государств Содружества (а где их нет - Верховных Судов), следовательно, в состав этого варианта Президиума Суда Содружества войдут председатели Конституционных (или Верховных) Судов государств СНГ и т.д. При вариантах 6) и г) состав Президиума Суда Содружества будет переменным, что необычно, но в данном случае целесообразно - просто будет несколько составов Президиума.

Что касается Пленума Высшего Суда Содружества, то его состав не должен быть переменным, членами Пленума должны быть все судьи всех составов коллегий Суда Содружества и все председатели Конституционных, Высших арбитражных (хозяйственных и иных высших органов, разрешающих в государствах Содружества экономические споры) и Верховных Судов всех государств Содружества.

Такой подход к формированию Президиума (имеется в виду последний вариант) и Пленума Высшего Суда Содружества позволяет, с одной стороны, квалифицировать вторую и третью его инстанции как коллегиальные органы, где будет обеспечена более высокая степень координации взаимодействия всех трех ветвей судебной власти в каждом государстве Содружества, с другой стороны - в отдельных случаях - как орган (здесь речь - о третьей инстанции) в иерархии судебных процедур более высокий, чем высшие судебные органы всех трех ветвей судебной власти государств Содружества, а отсюда, с третьей стороны, как орган (здесь речь о всех трех инстанциях), нуждающийся в наделении его правомочиями вынесения обязательньх к исполнению решений. Совет глав государств СНГ имеет полное право и реальную возможность наделить Высший Суд Содружества (и реформированный Экономический Суд СНГ) свойствами надгосударственного органа, что, безусловно, будет способствовать углублению интеграционных процессов в Содружестве.

Разумеется, реальный механизм обеспечения принудительного исполнения решений Суда Содружества придется серьезно отрабатывать на практике. В отличие от Суда Европейского Союза, где все решения исполняются автоматически, в нашем постсоветском обшестве всех без исключения государств Содружества, где "в законе" правовой нигилизм, а в деятельности отдельных учреждений подчас торжествует правовой 
цинизм, проблемы с обеспечением исполнительного производства даже национальных судов не скоро исчезнут, что уж говорить об исполнительном производстве международного суда. Но эта проблема решаема, в том числе - в части решений Высшего Суда Содружества. В зависимости от того, какая Коллегия выносит решение, и от предмета спора обеспечивать принудительное решение Суда Содружества будут органы, институты Содружества, национальные суды государств Содружества и соответствуюшие органы государственной власти и управления государств Содружества. В документах о Суде Содружества, которые утвердит Совет глав государств СНГ, вопросам исполнительного производства должно быть уделено самое серьезное внимание.

Наделение Суда Содружества правом вынесения обязательных к исполнению решений (впрочем, относительно отдельных категорий дел и споров может быть предусмотрено право вынесения лишь рекомендательных решений) проблему разрешения споров с участием сторон, на которых обязательная юрисдикция Суда Содружества не распространяется, не решит. Поэтому следует наделить Суд Содружества правом работать в режимах третейского судоустройства и третейского судопроизводства, и как институциональный третейский суд, и как третейский суд ad hoc, для рассмотрения как межгосударственных споров, так и споров с иным субъектным составом.

Процедура урегулирования и разрешения межгосударственного территориального спора в СНГ от, К примеру, рассмотрения трудового спора с участием органа, института СНГ, отличаться должна существенно. Поэтому необходима будет тщательная проработка регламента деятельности каждой коллегии Суда Содружества, включая вопросы внесудебной и досудебных стадий урегулирования споров каждой категории. Но в целом процедуры работы всех коллегий на всех стадиях должны быть инкорпорированы в единый процессуально-процедурный акт типа Процессуального кодекса Суда Содружества.

1 Ржсевкий B.A. О юридической природе форм нового Содружества Независимых Государств.//Государство и право. - 1992. - №6. - с.34.

${ }^{2}$ Бекмурзаев B.A. Миротворческая роль России в урегулировании вооруженных конфликтов в СНГ.//Государство и право. - 1994. - №12. - с.3.

3 Чернышев $C$. Территориальные притязания выходят из анабиоза.//Газета "24", 1995, 28 февраля.

4 Симонян Г.В. К вопросу о признании юрисдикции Экономического Суда СНГ государствами-членами Содружества Независимых Государств.//Вестник Высшего Арбитражного Суда Российской Федерации. - 2000. - №4. - c.103-109.

г. Тюмень

Статья поступила в редакцию в июне 20002. 